\title{
IMPROVING THE SPHERE OF HOUSEHOLD WASTE MANAGEMENT IN SAINT PETERSBURG
}

\section{Evgeny Safonov}

Russian State University for the Humanities (Domodedovo), Moscow, Russia

\section{Sergey Kirsanov}

Russian State University for the Humanities (Domodedovo), Moscow, Russia https://orcid.org/0000-0002-5932-8989

\section{Galina Palamarenko}

Russian State University for the Humanities (Domodedovo), Moscow, Russia

OMESTE

JEL Category: H54

\begin{abstract}
The problem of removing and neutralizing household waste is becoming more acute every year and occupies the main place for any city. This is explained by the fact that waste negatively affects the environment and the person who is the producer of this waste and causes great harm to the economy. On the other hand, the waste itself is the richest source of secondary resources, it is also a "free" energy carrier since household waste is a renewable energy raw material for fuel energy. The state of the environment on the territory of Russia is determined by a high technical load, as well as a long-term and sustained negative impact, including due to the formation and accumulation of production and consumption waste. Of all the garbage produced in Russia, the largest share falls on solid household waste - more than $25 \%$. Only 3-5\% of them are sent for recycling, and the rest - in a landfill. The situation in the field of waste management in St. Petersburg and the Leningrad Region and the presence of many unauthorized dumps causes serious public concern. The article formulates recommendations to improve the efficiency of organization and management of municipal waste management, addressed to the heads of state and municipal authorities and management.
\end{abstract}

Keywords: solid household waste, management, separate collection of waste, waste management, municipal waste management 


\section{INTRODUCTION}

The Earth's ecosystem, which is home to 7.8 billion people and more than 8.7 million animal species, is in a state of imbalance due to anthropogenic activities. An ever-growing population and industrialization pose an acute threat to the ecosystem. 502 kgs of municipal waste per capita were generated in the EU in 2019. This is an urgent problem since open landfills and incineration of waste create catastrophic environmental consequences.
In 2018, the total waste generated in the EU by all economic activities and households amounted to 2337 million tons. (Eurostat, 2021)

The EU's waste management policy aims to reduce the environmental impact of household waste and improve the efficiency of resource extraction from waste. The European Green Deal promotes the transition to a resource-efficient and competitive economy. As part of this transition, a few EU laws on household waste will be revised.

Table 1-Waste generation by economic activities and households, 2018 (\% share of total waste)

\begin{tabular}{|c|c|c|c|c|c|c|}
\hline & $\begin{array}{c}\text { Mining and } \\
\text { quarrying }\end{array}$ & Manufacturing & Energy & $\begin{array}{l}\text { Construction } \\
\text { and demolition }\end{array}$ & $\begin{array}{c}\text { Other } \\
\text { economic } \\
\text { activities }\end{array}$ & Households \\
\hline EU & 26.6 & 10.6 & 3.4 & 35.9 & 15.4 & 8.2 \\
\hline Belgium & 0.1 & 24.9 & 1.2 & 33.5 & 33.1 & 7.2 \\
\hline Bulgaria & 82.4 & 2.0 & 10.0 & 0.1 & 3.1 & 2.4 \\
\hline Czechia & 0.2 & 14.6 & 1.5 & 41.7 & 26.7 & 15.3 \\
\hline Denmark & 0.0 & 4.7 & 5.1 & 56.0 & 17.8 & 16.4 \\
\hline Germany & 2.2 & 13.9 & 2.3 & 55.5 & 16.8 & 9.2 \\
\hline Estonia & 29.5 & 18.8 & 32.3 & 9.5 & 7.6 & 2.4 \\
\hline Ireland & 14.2 & 24.7 & 1.1 & 13.6 & 35.1 & 11.4 \\
\hline Greece & 56.4 & 11.8 & 7.6 & 5.0 & 9.2 & 10.1 \\
\hline Spain & 17.1 & 9.9 & 2.4 & 27.6 & 26.5 & 16.5 \\
\hline France & 0.4 & 6.6 & 0.4 & 70.2 & 13.7 & 8.7 \\
\hline Croatia & 12.0 & 8.9 & 1.3 & 22.7 & 31.7 & 23.3 \\
\hline Italy & 0.8 & 16.5 & 1.3 & 35.3 & 28.7 & 17.5 \\
\hline Cyprus & 6.6 & 16.3 & 0.1 & 45.8 & 14.5 & 16.8 \\
\hline Latvia & 0.1 & 21.7 & 2.5 & 17.5 & 25.7 & 32.6 \\
\hline Lithuania & 1.6 & 37.2 & 2.1 & 8.8 & 30.3 & 20.0 \\
\hline Luxembourg & 0.0 & 6.9 & 0.1 & 81.2 & 9.7 & 2.1 \\
\hline Hungary & 1.0 & 14.3 & 11.2 & 33.2 & 25.4 & 14.9 \\
\hline Malta & 1.6 & 1.0 & 0.0 & 78.8 & 11.2 & 7.4 \\
\hline Netherlands & 0.0 & 9.6 & 1.1 & 70.0 & 13.3 & 6.0 \\
\hline Austria & 0.1 & 8.7 & 0.8 & 74.4 & 9.3 & 6.7 \\
\hline Poland & 36.7 & 17.0 & 10.7 & 9.7 & 20.6 & 5.3 \\
\hline Portugal & 0.2 & 19.0 & 1.1 & 8.8 & 38.1 & 32.8 \\
\hline Romania & 88.0 & 3.9 & 3.4 & 0.3 & 2.4 & 2.1 \\
\hline Slovenia & 0.2 & 20.2 & 11.8 & 8.1 & 51.9 & 7.8 \\
\hline Slovakia & 2.2 & 27.5 & 7.9 & 4.4 & 39.8 & 18.2 \\
\hline Finland & 74.9 & 6.7 & 1.0 & 12.3 & 3.5 & 1.6 \\
\hline Sweden & 74.7 & 3.7 & 1.4 & 8.9 & 8.0 & 3.2 \\
\hline Iceland & 0.0 & 24.4 & 0.0 & 3.9 & 31.5 & 40.2 \\
\hline Liechtenstein & 1.6 & 1.5 & 0.0 & 88.6 & 1.6 & 6.7 \\
\hline Norway & 1.2 & 12.8 & 1.5 & 40.0 & 27.4 & 17.1 \\
\hline Montenegro & 27.4 & 3.7 & 27.6 & 11.3 & 8.6 & 21.4 \\
\hline North Macedonia & 14.2 & 46.6 & 0.5 & 3.1 & 35.6 & 0.0 \\
\hline Serbia & 75.6 & 2.9 & 14.7 & 1.1 & 2.1 & 3.6 \\
\hline Turkey & 17.9 & : & 26.1 & 0.0 & 7.1 & 28.9 \\
\hline Bosnia and Herzegovina & 8.2 & 28.1 & 48.1 & 1.8 & 0.2 & 13.6 \\
\hline Kosovo $\left({ }^{1}\right)\left({ }^{2}\right)$ & 93.5 & 2.0 & 3.4 & 0.1 & 0.0 & 1.0 \\
\hline
\end{tabular}

(1) 2016

(2) This designation is without prejudice to positions on status and is in line with UNSCR 1244/1999 and the ICJ Opinion on the Kosovo Declaration of Independence

Source: (Eurostat, 2021) 
To monitor the implementation of waste policies, in particular compliance with the principles of recovery and safe disposal, reliable statistics on the production and management of waste from enterprises and private households are needed. In 2002, Regulation (EC) No 2150/2002 on waste statistics was adopted, creating the basis for harmonized Community statistics in this area. Since 2004, the Regulation has required the EU Member States to provide data on the generation, disposal, and disposal of waste every two years. Waste generation and treatment data are currently available for the reporting years from 2004 to 2018.

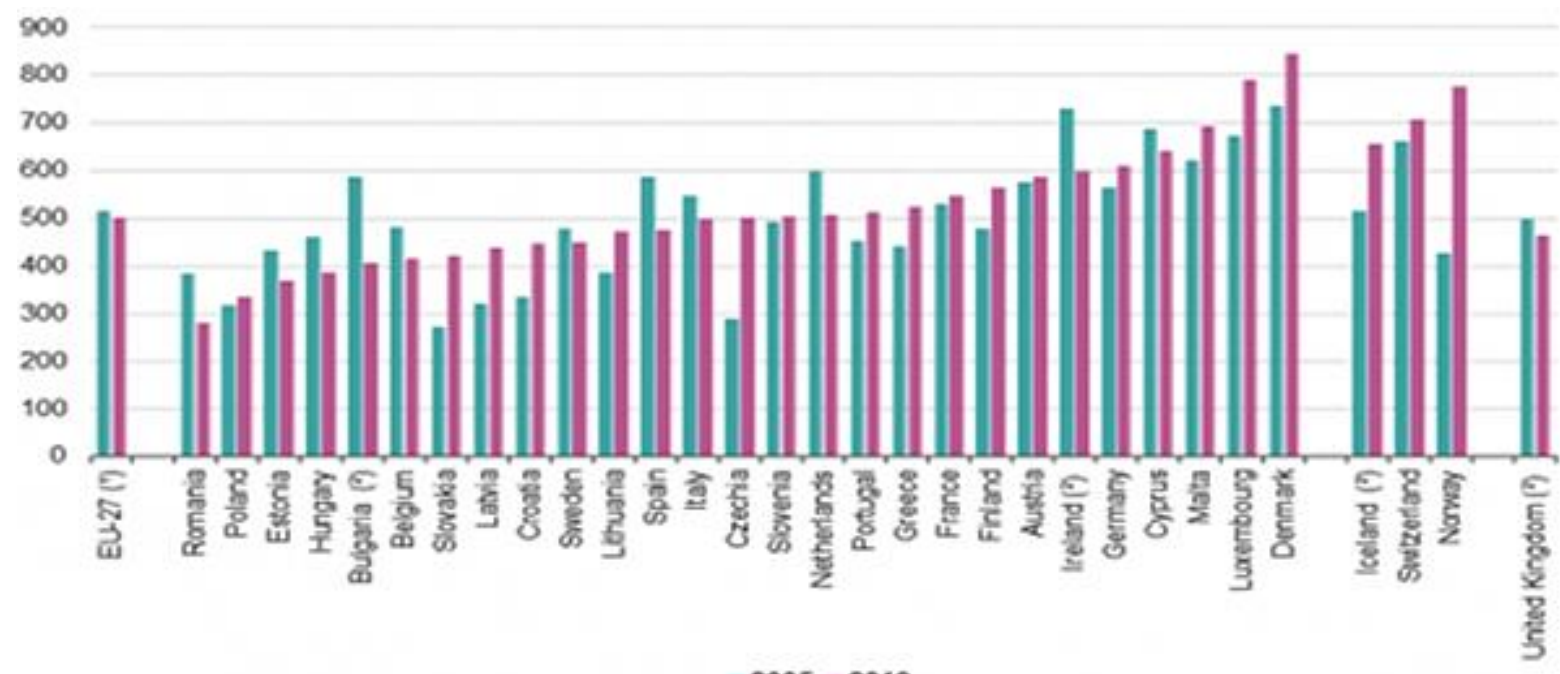

Note: Countries are ranked in increasing order by muncipal waste generation in 2019

(9) Estimated.

(2) Buloaria, Ireland, Unted Kingdom 2018 data, Iceland 2017 data

Figure 1: Municipal waste generated, 2005 and 2019 (kg per capita)

In 2019, the export of processed raw materials from EU member states to non-EU countries amounted to 25.5 million tons. Compared to 2004 , the volume of waste exports increased by $61 \%$. (Treus, 2020)

The 1989 Basel Convention on the Control of Transboundary Movements of Hazardous Wastes and their Disposal defines waste as a substance or article that is disposed of, intended for, or intended to be disposed of following national legislation. (UNEP, 1989)

National legislation defines the production and consumption of waste as substances or objects generated during the production, performance of works, provision of services or consumption of substances, or objects generated during the disposal of such substances or objects.

\section{SITUATION \\ IN \\ THE \\ ORGANIZATION OF SOLID WASTE COLLECTION, DISPOSAL, AND RECYCLING IN RUSSIA}

The state of the environment on the territory of Russia is determined by a high technical load, long-term and stable negative impact on natural complexes, including, through the formation and accumulation of production and consumption waste.

Industrial development strategy of processing, utilization, and disposal of production and consumption for the period up to 2030 is the industry strategic planning document and determines the priorities of the national policy in the field of development of production and consumption waste in the industry, the creation and development of processing of waste production and technological complexes necessary and adequate conditions, strategic vision goals and objectives, as well as action and implementation arrangements necessary for its development. (Government RF, 2018)

In 2019, the Russian population left behind about 346 million cubic meters (or about 64 million tons) of waste. At the same time, almost 48 million tons of such waste went to landfills and just over 18 million tons went to sorting. Sorting facilities are also still problematic as only 206 such enterprises are operating in Russia. That is, currently only a third of all municipal solid waste is sorted. The 
appearance of new centers will help to correct the situation. The authorities want to build 360 such facilities. The remaining waste is sent to landfills, which are already unable to cope with the incoming volumes. At the end of September 2020, the Accounts Chamber of the Russian Federation reported that the situation with official landfills is close to critical. Given the growth rate of the solid household waste (SHW) volumes (1-2\% per year) in 32 regions, they will be filled by 2024, and in 17 - by next year. (Babaeva, 2021)

For many years, the waste recycling industry in Russia has not developed, negatively affecting the environment. This shift was outlined only a few years ago when public organizations and the State were engaged in this issue. The Ministry of Natural Resources and Ecology of the Russian Federation monitors the state of the environment and develops departmental regulations. The experience of our foreign colleagues, who have long been very successful in solid waste management, serves as a guide.

The state of the ecosystem of the North-Western region of Russia is such that most landfills need to be either closed or upgraded, as they do not meet environmental safety standards and cause enormous damage to the local ecosystem, polluting the soil, ground, and surface water with toxic substances. Territorial waste management schemes should not only provide for separate waste collection, as is the practice in many developed countries but also address the issue of disposal of accumulated damage.

\section{PROBLEMS OF FUNCTIONING OF THE SHW COLLECTION, RECYCLING AND RECYCLING SYSTEM IN SAINT PETERSBURG}

Saint Petersburg is one of the five regions of the Russian Federation that generate the most waste. Analysts of the international audit and consulting network FinExpertiza estimated, that the northern capital produces about 11.1 million $\mathrm{m}^{3}$ of SHW. (Rudas, 2020) For comparison, Moscow produces 26,8 million $\mathrm{m}^{3}$ of SHW. (Babaeva, 2021)

Despite the transition to separate waste collection announced at the federal level, in St. Petersburg, the implementation of this mechanism is stalled: the practice of separate collection is in its infancy, and the city authorities have not created and do not plan to create a legislative framework in the foreseeable future. In St. Petersburg and the Leningrad region, garbage collection has become quite a sore issue, which should have been addressed for a long time. According to experts, $90 \%$ of St. Petersburg's waste is taken to landfills in the neighboring region - and the governor of the Leningrad Region has already initiated a doubling of sanitary zones around landfills (from the standard $1 \mathrm{~km}$ to $2-3 \mathrm{~km}$ ). (Rudas, 2020)

The following types of waste predominate in solid waste in St. Petersburg (\%): food waste -27.4 , paper and cardboard -21.5 , plastics -11.9 , glass - 8.9. Useful components (potential secondary raw materials) and mixed solid waste are divided approximately equally. For the projected amount of SHW in 2040, there will be an amount of 1,250 thousand tons for secondary resources and 1,250 thousand tons of mixed waste.

Decree of the Government of St. Petersburg No. 487 of 17.06.2014 "About the state program of Saint Petersburg "Improvement and environmental protection in Saint Petersburg" (Resolution 487, 2014) the target indicators reflecting the efficiency of implementation of the state program are established. When calculating the target indicator "Increase in the number of treated, disposed, and neutralized SHW in the total volume of waste generated" the forecast values of the total capacity of enterprises are considered, considering the measures implemented by investors under the agreements (Table 2).

The main goal of the state program of St. Petersburg in the field of waste management is to establish the maximum reduction in the level of environmental hazards and harmful effects of solid waste. The impact on the health of St. Petersburg residents, as well as reducing the volume of direct landfill waste disposal. The main task is to modernize existing facilities and build new ones in the field of waste management with SHW. In addition, an increase in the maximum level of waste recycling is required. Solving the problem of waste disposal is possible only through the integrated application of technological, economic, and legal means of regulation. It is necessary to search for new and implement existing technologies to reduce waste generation, their processing, and recycling of the obtained secondary resources. (Resolution 487, 2014) 
Table 2 Increase in the number of treated disposed and neutralized MSW in the total volume of generated waste

\begin{tabular}{|l|c|c|c|c|c|c|}
\hline \multicolumn{1}{|c|}{ Name of the target indicator } & \multicolumn{3}{|c|}{ The direct value of the target indicator by year } & $\begin{array}{c}\text { Final } \\
\text { value }\end{array}$ \\
\cline { 2 - 7 } & $\begin{array}{c}\text { [\% } \\
\text { of the 2017 } \\
\text { target }\end{array}$ & 2018 & 2019 & 2020 & 2021 & 2022 \\
\hline $\begin{array}{l}\text { Increase in the number of treated, } \\
\text { disposed, and neutralized MSW in } \\
\text { the total volume of generated waste } \\
\text { (compared to the level of 2016) }\end{array}$ & - & 2.9 & 2.9 & 21.3 & 21.3 & 21.3 \\
\hline
\end{tabular}

Source: (ASPb, 2021)

By Decree of the Government of St. Petersburg, the forecast of the needs of the population of St. Petersburg for solid waste treatment, disposal, neutralization, and placement facilities has been adopted. According to the forecast, by 2022, the ratio of the total capacity of SHW processing, recycling, and neutralization facilities to the total volume of SHW generated will be $38.40 \%$, and by 2025 - 69.20\%. (Postanovlenie N457, 2017)

Garbage dumps in St. Petersburg are mostly located outside the city limits. In total, there are more than two dozen of them, but many of them are illegal and it is impossible to export solid waste to them. Despite this, waste removal is still carried out on them. Elf it is considered that the area of influence of SHW disposal facilities on the environment and public health is much larger than the area of their land plots, then the area of sanitary protection zones of waste disposal facilities should also be included in the consideration. Then we get that the area of the territory alienated by solid waste disposal facilities, considering their sanitary protection zones, is 8239 hectares, including 3880.2 hectares in the territory and St. Petersburg.

The main enterprises specializing in mechanized solid waste processing in St. Petersburg, are the state enterprise "Plant for mechanized processing of household waste" and its branch. These plants process about $20 \%$ of the total volume of solid waste generated in the city, the remaining $80 \%$ of waste is buried in polygon solid waste landfills. Moreover, after mechanized processing, an unprocessed residue weighing about $15 \%$ of the initial mass of SHW entering for processing is formed. This residue is also buried in landfills.

In St. Petersburg, waste collection and removal is provided by more than 300 organizations operating in the field of waste management, including more than 50 organizations that serve the housing stock.

We must admit difficult financial situation of enterprises providing waste disposal services is difficult due to the high cost of such services. The main debtors of enterprises that provide waste disposal services are the population.

An important problem is the lack of quality separate training facilities. The situation with primary waste sorting is very difficult. Special containers are installed in individual locations. In most yards, there are still old-style garbage cans, in which all the garbage is thrown into one pile and taken out. It is obvious that in St. Petersburg it is necessary to introduce separate waste collection at the legislative level. The experience of Moscow and the Moscow Region has shown that the creation of rules of the game in the field separate waste collection encourages the arrival of large players in this industry and, in general, allows you to increase the volume of recycled waste and the efficiency of their processing. At the same time, it is important to rely on the existing practices of business and civil society activists, so as not to destroy the sprouts of SHW, which were able to break through despite the legal vacuum.

Despite the passive position of the city authorities, the introduction of separate waste collection in St. Petersburg has growth drivers - these are ecoactivists and businesses. According to the Recycle map aggregator, the city has already installed more than 1,000 containers for collecting various categories of waste: old clothes, batteries, hazardous waste, etc. All this is the work of local environmental initiatives and local businesses. A study by the Public Chamber of St. Petersburg showed that $96 \%$ of St. Petersburg residents are already ready to switch to separate waste collection. (Rudas, 2020) 
For separate garbage collection in St. Petersburg and the Leningrad Region, the following container colors are used:

- Blue - for paper waste

- yellow - for plastic waste.

- red-for glass products.

- gray - for electrical equipment that has failed.

- green-for the SHW without sorting.

- orange - hazardous waste.

According to the results of the inventory, 33430 containers for collecting solid waste and largesized waste were considered, including:

- 16485 SHW collection containers are installed on land-based container sites.

- $\quad 496$ containers of the buried type are installed on container platforms.

- 16449 containers are installed in waste collection chambers. Depending on the location, the volume of containers used varies.
Containers are used at equipped collection sites $60 \%$ containers with a capacity of 0.75 cubic meters, $30 \%$ containers with a capacity of 6 cubic meters, and $10 \%$ containers with a capacity of 14 cubic meters are used at equipped collection points. (Chudakova, 2016) The design, technical condition, marking, and appearance of containers for collecting solid waste, specialized automobile transport used to ensure the collection and transportation of solid waste, generally meet modern technologies.

In the Northern Capital in the current period, issues related to the preparation of the existing SHW management system for modernization began to be resolved. As can be seen from Fig. 3, provides for a significant increase in funding for 2021, as well as 2022 and 2023, compared to 2020.

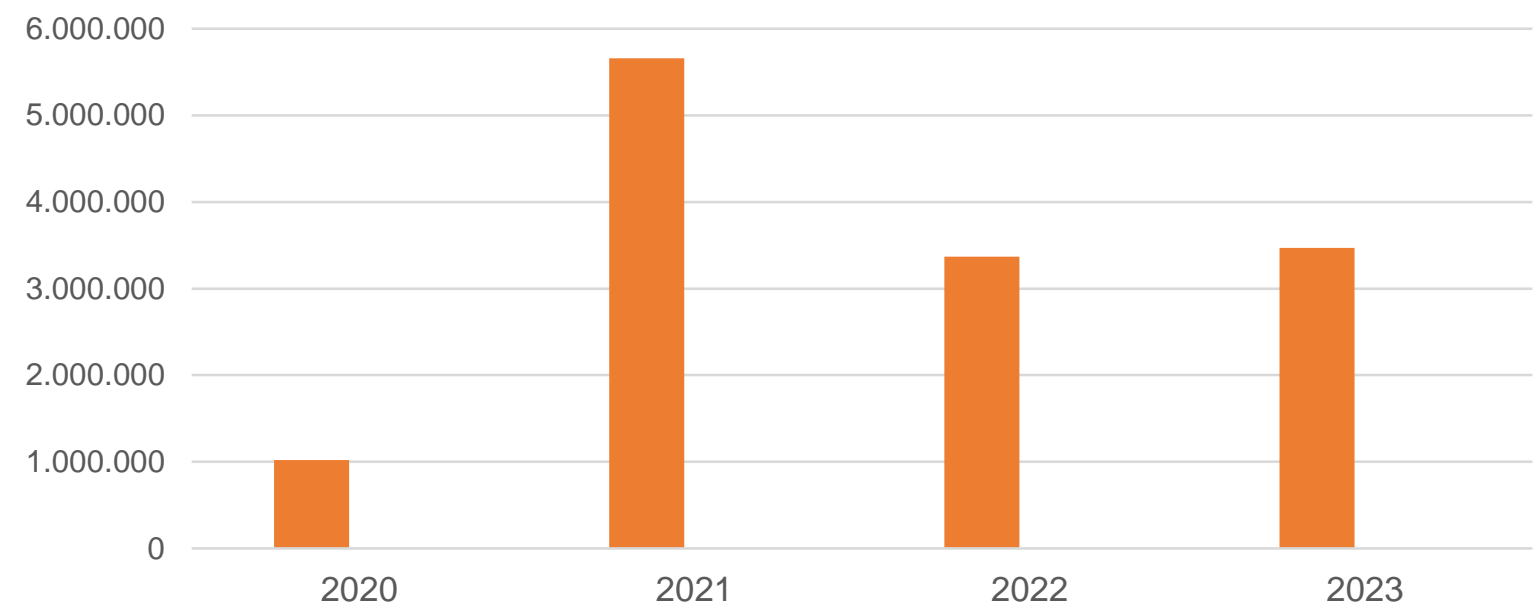

Figure 3 Dynamics of funding from the Saint Petersburg city budget for the state program "Improvement and Environmental protection in Saint Petersburg", 2020-2023, thousand rubles

Source: (komfinspb, 2021)

The separate waste collection program in St. Petersburg started on January 1, 2020, so the city and. The Leningrad Region is gradually switching to a new method of handling c SHW. The number of collection points for sorted garbage has significantly increased. All new buildings are equipped with special containers. This stage can be considered a transition in terms of moving towards separate garbage collection. There is a problem in storing waste that is already divided into fractions. There is also a problem in the maintenance of the separate SHW collection, where the main role should be played not only by management companies and specialized enterprises but also by consumers themselves, sorting garbage at home. To trust the system of separate waste collection, the population must understand why to sort waste, how to do it, and where it will end up in the future. Today, there is an urgent need to conduct awareness-raising activities among the population.

Almost all polygons in St. Petersburg and the Leningrad Region require urgent rehabilitation and recultivation. In many municipalities of the Leningrad Region, there are unauthorized landfills of industrial waste, for which there is no control, that is, the dumping of medical, toxic, and radioactive waste there is not excluded. 
In 2020, almost 600 illegal landfills were eliminated in the Leningrad Region. The total amount of garbage removed from illegal landfills amounted to more than 560 thousand cubic meters, which is 7 times more than in 2019. (online47.ru, 2020) Efforts to combat those who violate environmental laws are not being stopped. However, ecologists are convinced that no operational measures will help solve the problem of illegal landfills, and they are trying to completely change the system of waste removal and disposal.

Experts point out that the main product of recycling is supposed to be an RDF fuel ${ }^{1}$ for incineration plants, the construction of which is strongly opposed not only by environmentalists but also by residents of municipalities. The public also actively opposes the expansion of the capacity of existing landfills and the construction of new ones.

The government of the Leningrad Region agreed on an updated version of the territorial waste management scheme in July 2019 and is waiting for the completion of similar works by the government of St. Petersburg to synchronize them. The documents are necessary for the regions to fulfill the tasks of the regional project "Integrated system of municipal solid waste management" national project "Ecology". (AdSPb, 2021)

In the nearest future, the authorities plan - from the middle of the 2023 year in Saint-Petersburg and the Leningrad Region are going to open at least three deep waste recycling plants in St. Petersburg and the Leningrad Region from mid2023. (Drozdenko, 2020) There are only two years left before this deadline, but the regional authorities are not active in this direction.

An important problem of waste management and control is the practical lack of mandatory statistical reporting, a set of indicators and indicators that allow for sustainable monitoring of the state of waste management About in megapolis.

And, of course, there is the problem of creating an attractive regional investment policy that would attract investors' money to solve the problems under consideration.

\section{MEASURES TO IMPROVE WASTE MANAGEMENT IN ST. PETERSBURG}

To solve the existing problems, it is necessary to introduce a single approach for both regions along the entire technological chain of waste management-from separate collection "at the source" to the disposal of the inert part of solid waste. Construction of landfills, zoning of territories, consolidation of collection, processing, and disposal centers on the principle of "one landfill instead of hundreds of landfills".

Why is it necessary to develop a detailed Waste Management program in the Russian Federation, Saint Petersburg, and the Leningrad Region, which aims to cover all stakeholders as much as possible with an organized waste collection and disposal system? This system should be costeffective and ensure efficient collection and disposal of household waste. Realization is like this Waste management programs need an effective information and communication campaign to inform people about the new system, the feasibility of its implementation, and the potential results.

In our opinion, the solution of problems in the field of waste management should be carried out in the following areas:

1. Improvement of the existing SHW management system.

- development, adjustment, and implementation of sanitary cleaning schemes for all districts of Saint Petersburg.

- registration and certification of waste disposal sites.

- purchase and installation of containers for separate waste collection.

- purchase of vehicles for waste collection and transportation.

- conducting consistent and coordinated information and educational work with waste educators.

- development of feasibility studies for the construction of biogas recycling plants.
${ }^{1}$ RDF are granules compressed from crushed municipal solid waste and industrial waste, which are used to generate heat energy in kilns of cement plants, where a temperature of about 2000 degrees is maintained. 
- allotment of land plots for the construction of waste-processing / incineration plants.

- conducting an investment forum and attracting investors, holding tenders for the construction of these plants under the terms of a concession.

2. Implementation of many informational and organizational measures:

- formation of an information database of waste management at the level of two regions.

- development and implementation of information and analytical system for accounting, control, and management of waste flow and creation of an appropriate interface and thematic web page.

- preparation and approval of comprehensive waste management programs at the municipal level.

- development of logistics schemes for the movement of garbage collection equipment to optimize the costs of collecting and transporting SHW to their sorting and disposal sites.

- introduction of a system of measures for information and propaganda activities in the field of rational and safe waste management.

3. Implementation of several organizational and technical measures:

- Creation and implementation of a system for the permanent control and monitoring of the impact of waste disposal facilities on the environment.

- Substantiation of decisions on the optimal location of sites for the SHW processing and disposal plants.

- Development of design and estimate documentation and the gradual construction of modern plants for the processing and utilization of solid waste.
Planning and carrying out a set of measures to reclaim and sanitize the territories where the waste dumps are located. The implementation of these measures will contribute to:

- creating a viable and sustainable MSW management system.

- creating conditions for attracting investors for the construction of MSW processing and recycling plants.

- coverage of most of the population of both regions by a separate collection of "dry" resource-valuable components (paper, metal, plastic, and glass).

- provision of sanitary cleaning of settlements in the Leningrad Region and the territory of St. Petersburg.

- technical re-equipment and renewal of garbage truck and container fleets.

\section{CONCLUSION}

Thus, it is possible to state the low efficiency of the existing waste management scheme in St. Petersburg.

A regional policy should be developed that will turn waste into useful raw materials and fuel to produce green thermal and electric energy. We need a real garbage reform designed to solve the accumulated problems in this area.

We have developed proposals, aimed at improving the efficiency of the organization of household waste disposal and neutralization, including, the maximum possible coverage of the city's residents by an organized waste collection and disposal system. Waste management programs in St. Petersburg and the Leningrad Region should ensure efficient collection, removal, and disposal of solid household waste.

\section{WORKS CITED}

AdSPb. (2021, 11 17). Formirovanie kompleksnoi sistemi obrasheniia s tverdimi kommunalnimi othodami. Retrieved from Administratsiya Sankt-Peterburga: https://www.gov.spb.ru/gov/national_projects/30/

ASPb. (2021, 06 01). Komitet po blagoustroystvu Sankt-Peterburga. Retrieved from Administratsiya Sankt-Peterburga, https://www.gov.spb.ru/gov/otras//blago/

Babaeva, R. (2021, 04 26). Obshestvo potrebleniia: skolko musora mi proizvodim. Retrieved from RBK Trendy: https://trends.rbc.ru/trends/green/cmrm/608058d99a79474434696eee 
Chudakova, E. (2016). Optimizachiia system obrasheniia c TBO na primere g.SPb i LO. Retrieved 11 18, 2021, from https://pandia.ru/text/80/506/28892-4.php

Drozdenko, A. Y. (2020, 12 22). V Leningradskoi oblasti postroiat zavodi po glubokoi pererabotke musora . Retrieved from TASS: https://tass.ru/obschestvo/10323805

Eurostat. (2021, 04). Waste statistics. Retrieved from Eurostat Statistics Explained: https://ec.europa.eu/eurostat/statisticsexplained/index.php?title=Waste_statistics\#Total_waste_generation

Government RF. (2018, 0125$)$. Strategy for the development of the industry for the processing, disposal, and disposal of production and consumption waste for the period up to 2030. Retrieved from government.ru:

http://static.government.ru/media/files/y8PMkQGZLfbY7jhn6QMruaKoferAowzJ.pdf

komfinspb. (2021). Funktsional'naya struktura raskhodov byudzheta Sankt-Peterburga - 2022. Retrieved from Finance Committee of St. Petersburg: https://xn--90anfigdkpy.xn-p1ai/budget/info/expense

online47.ru. (2020, 12 22). S nachala goda $v$ Leningradskoi oblasti likvidirovali pochti 600 nelegalnih svalok. Retrieved from asninfo.ru: https://asninfo.ru/news/94506-s-nachala-goda-v-lenoblastilikvidirovali-pochti-600-nelegalnykh-svalok

Postanovlenie N457. (2017, 04 11). Ob utverzhdenii normativov gradostroitel'nogo proyektirovaniya Sankt-Peterburga. Retrieved from cntd.ru: https://docs.cntd.ru/document/456056520

Resolution 487. (2014, 06 17). Resolution of the Government of St. Petersburg dated June 17, 2014 No. 487 "On the state program of St. Petersburg" Improvement and environmental protection in St. Petersburg". Retrieved from Garant: https://base.garant.ru/22914729/

Rudas, P. (2020, 09 29). "Ne nash metod": chto proishodit s razdelnim sborom othodov v St.Peterburge. Retrieved from ецоиндустрs.py: https://news.ecoindustry.ru/2020/09/ne-nash-metod-chtoproishodi/

Treus, A. (2020, 03 31). Strani ES eksportirovali $25,5 \mathrm{~m} / \mathrm{n}$ ton othodov za god. Retrieved from Aussidlerbote Zeitung: https://aussiedlerbote.de/2020/03/strany-es-eksportirovali-255-mlntonn-othodov-za-god/

UNEP. (1989). Basel Convention on the Control of Transboundary Movements of Hazardous Wastes and Their Disposal. Retrieved from Basel.int: https://www.basel.int/Portals/4/Basel\%20Convention/docs/text/BaselConventionText-e.pdf

Received for publication:

Revision received:

Accepted for publication:
16.07.2021

19.11.2021

06.01 .2022

\section{How to cite this article?}

Style - APA Sixth Edition:

Safonov, E., Kirsanov, S., \& Palamarenko, G. (2022, 01 15). Improving the sphere of household waste management in Saint Petersburg. (Z. Cekerevac, Ed.) MEST Journal, 10(1), 50-59. doi:10.12709/mest.10.10.01.06

Style - Chicago Sixteenth Edition:

Safonov, Evgeny, Sergey Kirsanov, and Galina Palamarenko. 2022. "Improving the sphere of household waste management in Saint Petersburg." Edited by Zoran Cekerevac. MEST Journal (MESTE) 10 (1): 50-59. doi:10.12709/mest.10.10.01.06. 
Style - GOST Name Sort:

Safonov Evgeny, Kirsanov Sergey and Palamarenko Galina Improving the sphere of household waste management in Saint Petersburg [Journal] // MEST Journal / ed. Cekerevac Zoran. - Belgrade Toronto : MESTE, 01 15, 2022. - 1 : Vol. 10. - pp. 50-59.

Style - Harvard Anglia:

Safonov, E., Kirsanov, S. \& Palamarenko, G., 2022. Improving the sphere of household waste management in Saint Petersburg. MEST Journal, 15 01, 10(1), pp. 50-59.

Style - ISO 690 Numerical Reference:

Improving the sphere of household waste management in Saint Petersburg. Safonov, Evgeny, Kirsanov, Sergey and Palamarenko, Galina. [ed.] Zoran Cekerevac. 1, Belgrade - Toronto : MESTE, 01 15, 2022, MEST Journal, Vol. 10, pp. 50-59 